\title{
Neotectonic activity in and around the southwestern Rhenish shield (West Germany) : indications of a levelling comparison
}

\author{
A. Demoulin ${ }^{\text {a,1,*}}$, A. Pissart ${ }^{a}$, K. Zippelt ${ }^{b}$ \\ ${ }^{a}$ Department of Physical Geography and Quaternary, Liege University, Allée du 6 Aô̂t, Sart Tilman-Liege, Belgium \\ ${ }^{b}$ Institute of Geodesy, Karlsruhe University, Englerstrasse, 7-Karlsruhe, Germany
}

Received 3 August 1993; accepted 26 January 1995

\begin{abstract}
Precise levelling data are re-examined in the southwestern Rhenish shield and its foreland by comparing them analytically along levelling profiles. Instead of generalizing regional vertical movement trends, this method emphasizes the activity of individual structural elements, which can be located with a high accuracy. It is shown that present-day vertical motions concentrate on fractures which cut the massif into a number of tectonic blocks. These undergo more or less independent movements. Significant measured displacements range from 1 to $3.5 \mathrm{~cm}$ over an average 20-year period and correspond mostly to aseismic slip. High displacements are found near pre-existing faults, sometimes also zones of joint concentration which are favourably oriented with respect to the current regional stress field. In the Mosel area, SW-NE-trending faults are predominantly reactivated as reverse faults. The motion inferred for the Hunsrück border fault is also consistent with the compressive regime presently observed in that area, with $\sigma_{1}$ oriented to the northwest. The direction of vertical motions along the western border fault of the upper Rhine graben changes from south to north in relation to the different azimuths of the central and northern segments of the graben, inducing a $\mathrm{S}-\mathrm{N}$-oriented transition from compressional to extensional shear. Within the graben itself, some $\mathrm{N} 160^{\circ} \mathrm{E}$-trending normal faults are identified, one of them having probably ruptured in a swarm of microearthquakes not long before the second survey was performed. The western Saar-Nahe trough is characterized by N-S-oriented fractures which cannot be related to mapped faults but show a close connection with photolineaments.
\end{abstract}

\section{Introduction}

There are strong geological and geomorphological indications that the western Rhenish shield has been uplifted since at least the Oligocene (Fuchs et al., 1983): Oligocene marine sands rest now on the highest parts of the Ardennes (Demoulin, 1989), the

\footnotetext{
* Corresponding author.

${ }^{\prime}$ Research Associate N.F.S.R.
}

Eifel (Sonne and Weiler, 1984) and the Hunsrïck mountains (Zöller, 1983), at altitudes of $700 \mathrm{~m}$ and more; Quaternary valleys are cut $200-300 \mathrm{~m}$ deep in the massif and many Quaternary terrace profiles are disturbed by recent faulting (Negendank, 1983). However, these data yield only a rough idea of the times of motion and its current amplitude and distribution. On the other hand, geodetic data supplies information on the present-day crustal movements, but needs to be interpreted in a detailed geological and geophysical frame. Attempts have been made 


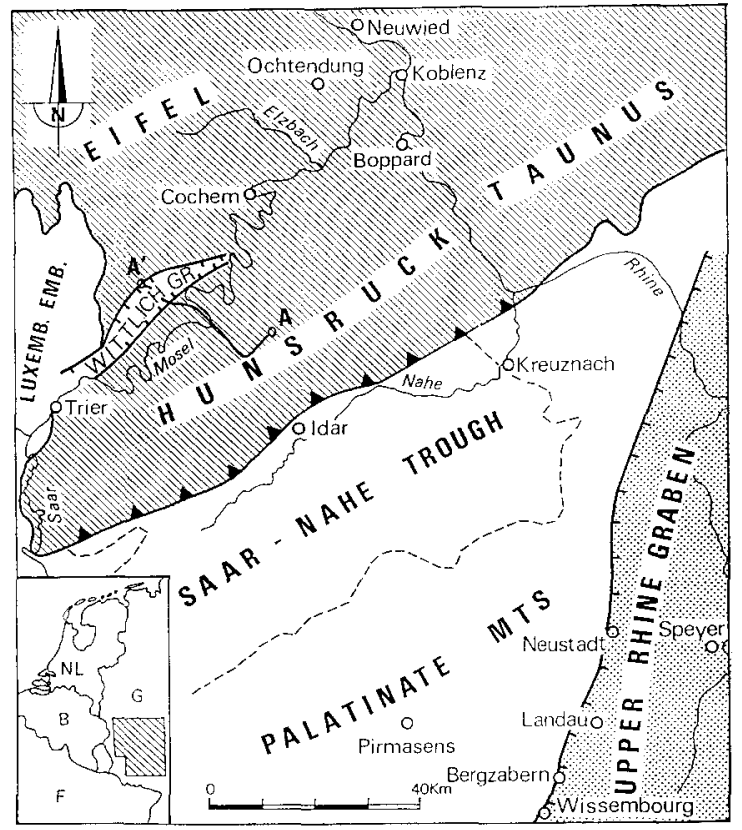

Fig. 1. Location of study area and places cited in the text. The line $A-A^{\prime}$ corresponds to the profile shown in Fig. 3.

therefore to use available geodetic data, i.e., successive precise levellings, in order to determine and quantify tectonic movements. For the southwestern part of the Rhenish shield, the map drawn by Mälzer et al. (1983) remains the best reference. They inferred height changes and vertical movement velocities for the whole massif from comparison of at least two successive precise levellings performed since 1921 in their study area. According to them, the massif is not uplifted uniformly: the uplift motions concentrate on limited areas, especially in the western Rhenish shield, whereas some parts of the massif east of the Rhine river are even subsiding. The highest uplift rates (up to $1.6 \mathrm{~mm} / \mathrm{yr}$ ) were observed in the West Eifel (Fig. 1). The South Eifel is slightly uplifting, while the Hunsrück is more or less stable, with only a limited updoming east of Trier. The Saar-Nahe trough and the Palatinate mountains display a more varied tectonic behaviour: a general trend to uplift is particularly marked in their eastern part, with movement rates up to $0.8 \mathrm{~mm} / \mathrm{yr}$ on the western shoulder of the upper Rhine graben, but one notes also a subsidence area southwest of Idar-Oberstein, near the Hunsrück border fault. Superimposed on these regional motions is an overall tilting to- wards the Rhine valley, running from north to south over the whole western Rhenish shield and its southern foreland. Within the upper Rhine graben, Mälzer et al. (1983) identify uplift motions west of the Rhine river, due to compressional shear (Illies and Baumann, 1982).

Similar work has also been completed in Belgium and northern France. Fourniguet (1987) showed that the Alsace, and, surprisingly, most of the Vosges mountains too, are currently subsiding. This is in contrast with the uplift motion of the Palatinate mountains. In eastern Belgium, Jones (1950) observed a considerable uplift of the Hautes Fagnes plateau at a rate of $2 \mathrm{~mm} / \mathrm{yr}$ during the first half of the 20th century, but Pissart and Lambot (1989) point out that, from 1948 to 1980 , the same region has subsided more than $40 \mathrm{~mm}$, at a time when the nearby Eifel mountains underwent continued strong uplift!

All these studies have largely contributed to outline the current vertical crustal movement pattern of the Rhenish shield and the adjacent areas. Unfortunately, most of them do not supply information about the present-day activity of individual structural features on the shield, inasmuch as they provide only smoothed maps of regional height change trends, after having selected representative benchmarks (Mälzer et al., 1983) or averaged the values for geographically clustered benchmarks (Pissart and Lambot, 1989). Much information is lost, therefore, on local anomalous height-change variations, which in some circumstances could betray current motion of individual structural elements, especially faults. To remedy this problem, we have processed the adjusted rates of vertical movement in an analytical way by direct interpretation of profiles along each first-order levelling line before mapping. This method has already been successfully applied, where either faults were suspected to be presently active (Vyskocil et al., 1991; Ellenberg, 1992), or where a coseismic movement had to be modelled (Stein and Barrientos, 1985), or systematically over wide areas (Fourniguet, 1987; Colleau and Lenôtre, 1991; Demoulin et al., 1992). Furthermore, such an analysis supplies more reliable results since significance thresholds are lowered by comparing adjacent benchmarks, generally not more than $1 \mathrm{~km}$ away from each other. 


\section{Database and method}

The study area corresponds to that part of the Rhenish shield which belongs to the RhinelandPalatinate land west of the Rhine river. Two precise levellings of first order are available in the complete network, the first one performed from 1949 to 1958 , the second one achieved between 1968 and 1973. Meanwhile some single levelling lines have been repeated once more. The density of comparable benchmarks is approximately 1 per $\mathrm{km}$ along the levelling lines. Special data corrections of the observed height differences due to theoretical error influences (level collimation, rod calibration, temperature, atmospheric refraction, rod orientation relative to sunlight) are discussed in Zippelt (1988) but they are not considered here for lack of necessary data information. Schematically, the mean systematic error on parts of the German geodetic network is estimated not to exceed $20 \%$ of the random error (AdV, 1975); moreover, its systematic character is strong only over short distances, and is generally lost when considering longer lines. Correlating the determined height change variations to the levelling route topography, no significant extended regression coefficients were found. This indicates the absence of height-dependent systematic errors.

The survey accuracy is thus strongly dependent on random errors. During levelling, the successive sections (distance between pairs of adjacent benchmarks) are generally surveyed twice, the forward and backward measured height differences between the benchmarks being usually slightly discrepant; the standard deviation of these discrepancies (whose distribution is assumed to be Gaussian in form) for all levelling sections indicates the accuracy of the levelling. Mälzer et al. (1983) computed standard deviations for all first-order levelling lines of both Rhineland-Palatinate surveys to be $0.2-0.5$ $\mathrm{mm} / \mathrm{km}^{1 / 2}$. These were then used to obtain the cumulative random error on a levelling line, following the formula $\sigma=\eta L^{1 / 2}$ with $\sigma=$ cumulative random error, $\eta \cong$ standard deviation and $L=$ line length in kilometres (Bomford, 1971). If $\eta_{1}$ and $\eta_{2}$ denote, respectively, the standard deviations of the first and the second levelling, the cumulative random error for height changes $(\Delta h)$ in that timespan is given by $\sigma_{\mathrm{c}}=\left(\eta_{1}^{2}+\eta_{2}^{2}\right)^{1 / 2} L^{1 / 2}$.

Our method of analytical levelling comparison, improved from the general principles exposed by Fourniguet (1987), is based on profiles which indicate changes of height differences of two adjacent benchmarks. However, because of highly variable timespan between the surveys for each benchmark, only a velocity model was suitable to model the point movements. Based on, and combined with a single-point model by Holdahl (1975), which yields adjusted time-dependent heights, different functional

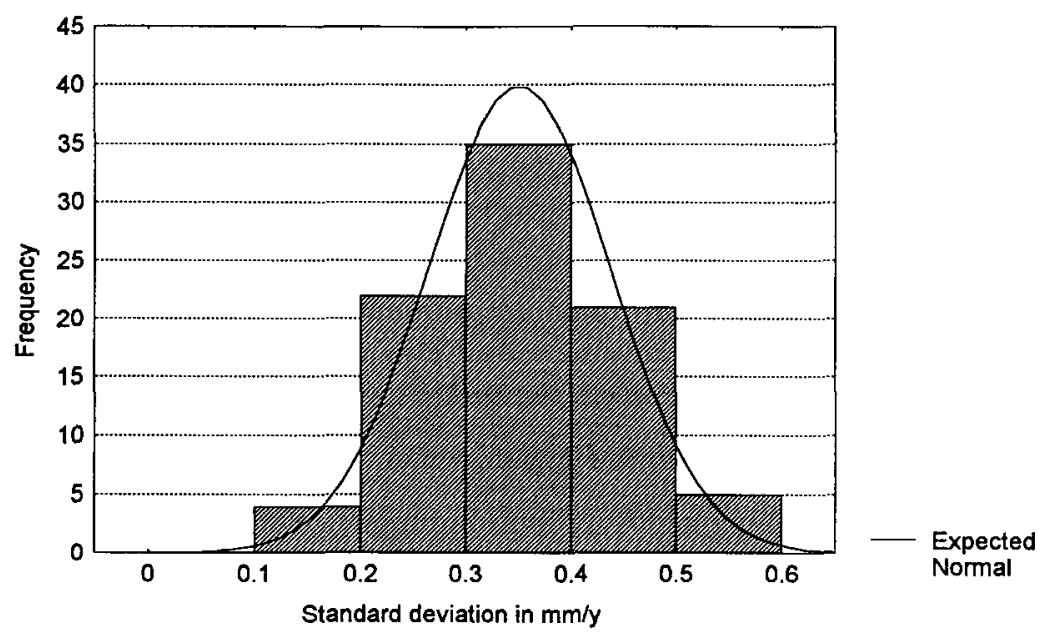

Fig. 2. Distribution of movement rate standard deviations (in $\mathrm{mm} / \mathrm{yr}$ ) for the junction points of the Rhineland-Palatinate first-order network used to compile the recent crustal movement map of the European geotraverse (after Zippelt, in Blundell et al., 1992). 
models to estimate vertical motions have been discussed by Zippelt (1988), and a stepwise procedure has been proposed to obtain information about the height changes of the used benchmarks. After statistically defining the best fitting model of the motions by adjustment of all height differences, a network composed of the junction points and of secondary junction points defined where levelling has been interrupted for a timespan exceeding one year, is fixed by several representative benchmarks supposed to be stable. The results of these computations are used to investigate the whole network line by line separately. By this way movement rates and standard deviations of all comparable points are determined along the levelling lines. Based on that procedure (morc extensively discussed in Mälzer et al., 1983), Fig. 2 shows the distribution of movement rate standard deviations for the junction points used in southwestern Germany to compile the recent crustal movement map of the European geotraverse (Blundell et al., 1992). Thus, profiles representing individual movement rates for each point were drawn (Fig. 3). In order to express more clearly some movement values (for instance the tilting of blocks), we have lurther assumed that motions were linear on a period of 20 years, averaging the timespan between successive measurements, and we have transposed the velocity profiles on profiles giving the total amount of movement over that 20-year period. Nevertheless, the chart with the $\sigma_{c}$ and $2 \sigma_{c}$ curves (plotted against $L$ ), which determine the significance thresholds for the height change analysis, has been drawn at a scale which is considered the worst possible situation (Fig. 3), i.e., some benchmarks may have been relevelled only 11 years after their first measurement (19571968).

Profile interpretation assumes that the levelling lines are divided into a number of segments which correspond to zones of different tectonic behaviour and diverse movement. A mean profile line is thus defined, composed of segments approaching, at best, the real profile. Their delimitation and the significance of their slope are defined on the basis of the $\sigma_{\mathrm{c}}$ curve. The junctions between adjacent segments, which we shall call motion discontinuities, can be characterized only by simple inflexion points separating segments of significantly different slope (at the $1 \sigma_{c}$ confidence level) or by vertical offsets, either progressive, indicating the presence of flexures, or abrupt when resulting from a fault movement. Most of the motion discontinuities discussed below are such segment junctions, characterized by a sharp slope change associated with a significant vertical displacement. However, fault movement may also be indicated by abnormal points on the profile; these points, interrupting abruptly the segment continuity, are defined as lying outside the $2 \sigma_{c}$ curve adjusted on the mean segment line. As the longest segment identified in Rhineland-Palatinate is $74 \mathrm{~km}$ long, the cumulative error on a segment never exceeds $6.1 \mathrm{~mm}$ (with $\eta_{1}=\eta_{2}=0.5 \mathrm{~mm} / \mathrm{km}^{1 / 2}$ ); at the $95 \%$ confidence level, every anomalous point which departs from the mean segment line of more than $(2 L)^{1 / 2} \mathrm{~mm}$, with $L$ counted in kilometres from the starting point of the segment, is described as a levelling anomaly; at a distance of $74 \mathrm{~km}$, this is at least $12.2 \mathrm{~mm}$ higher or lower than the segment line.

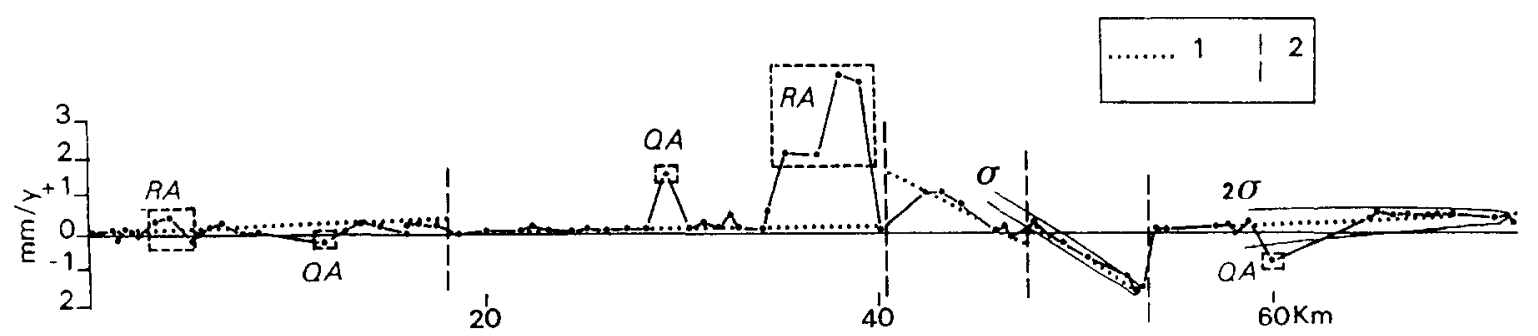

Fig. 3. Height change variation profile between Gödenroth (Hunsrück) and Wittlich (southern Eifel). $I=$ smoothed line of a profile segment, corresponding to a zone of homogeneous height change; $2=$ segment junction; $R A=$ reliable motion anomaly $\left(|\Delta h|>(2 L)^{1 / 2}\right.$ $\mathrm{mm}$ relative to the segment line, see further explanation in text); $Q A=$ questionable anomaly (geodetically significant but tectonically uncertain). The $\sigma$ and $2 \sigma$ curves in the right part of the profile highlight quality of data and significance of the proposed segmentation. 


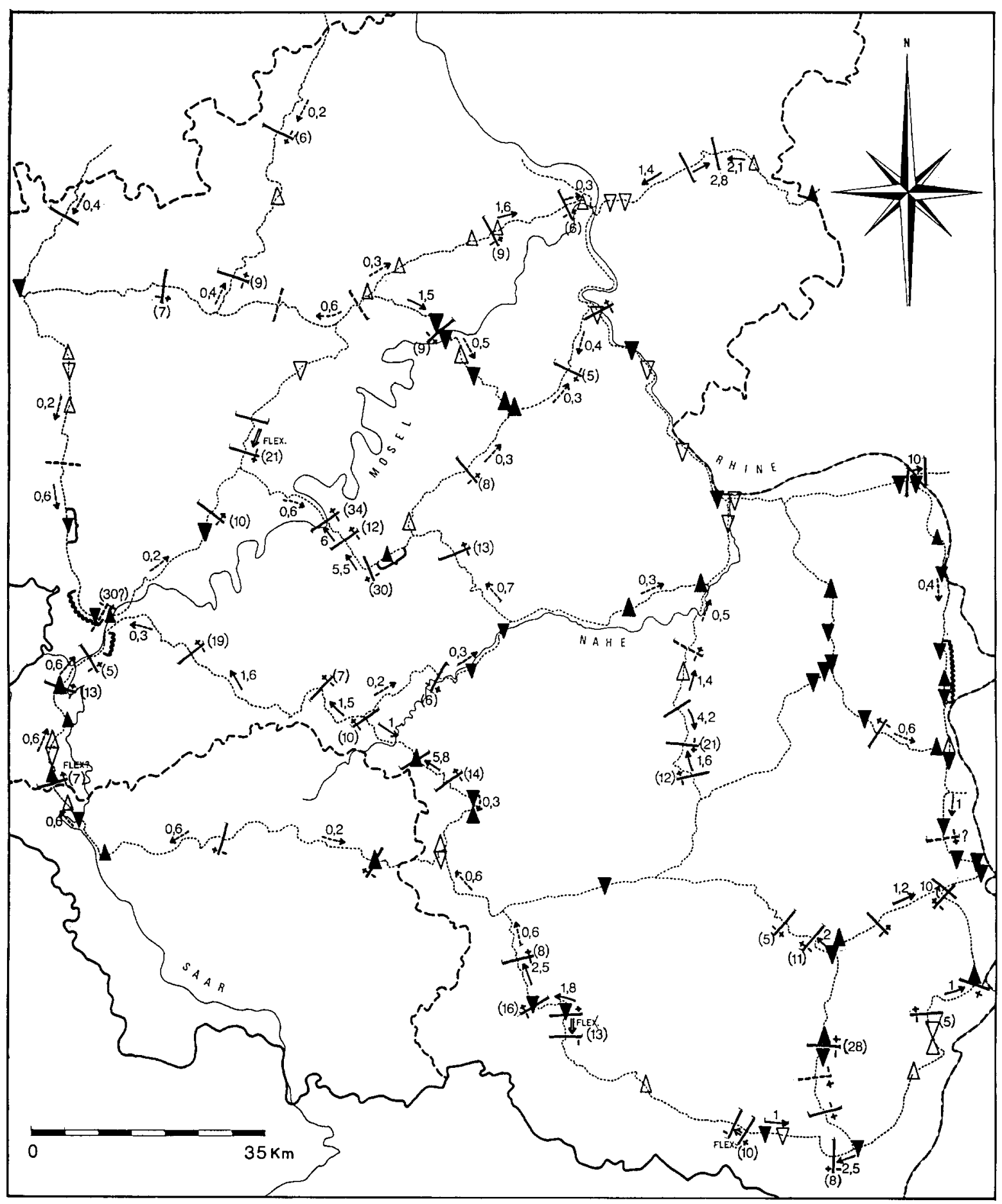

Fig. 4. Map of the motion discontinuities and anomalies. A bar on a profile denotes a motion discontinuity; if accompanied by $+/-$, a vertical displacement whose value in $\mathrm{mm}$ for a 20 -year period is given in brackets. Solid triangles denote reliable local anomalies, positive or negative; open triangles are for questionable anomalies. Arrows point down to the tilted segments; tilt value is given in $\mathrm{mm} / \mathrm{km}$ for a 20-year period. 
These geodetically significant anomalies must furthermore be tested for their tectonic significance; their reliability was first assessed by field checking of the benchmarks, by considering the direction of the anomalous motion and by the number of clustered anomalous points. Every isolated benchmark displaying height change $100 \mathrm{~mm}$ larger than adjacent benchmarks has further been eliminated, except if it belonged to a special segment configuration (see, for instance, profile $\mathrm{A}^{\prime}-\mathrm{A}^{\prime \prime}$ in Fig. 7). Lastly, subsidence effects induced by a progressively lowering water table have been analysed by Hein (1978) in the northern Rhine graben, but such subsidence appears unlikely in most of the study area (Rhenish shield, Saar-Nahe trough and Palatinate mountains).

In a second step of the analysis, all discontinuities and tectonically significant anomalies identified on the profiles are mapped (Fig. 4) and relationships are established between them, the interpolation within the levelling polygons being carefully carried out with reference to the type of discontinuity or anomaly and the regional structural pattern.

\section{Analysis of the map of motion discontinuities}

The analysis of motion discontinuities and anomalies leads us to split up the western Rhenish shield and its southern foreland into a number of different tectonic blocks, separated by motion discontinuities mostly occurring on faults (Fig. 5). At first sight, the fracture pattern characterizing the whole study area (including Rhenish massif, foreland and even the northwestern Rhine graben) is uniform: alternating homogeneous, more or less stable zones, with densely fractured zones of tilted blocks. In detail however, the dominant fracture direction and the nature of the movement are particular to each zone.

North of the Mosel river, the southwestern Eifel mountains can be considered as a relatively homogeneous and stable region with at most a slight downwarping to the southwest. It is traversed, however, by some NW-SE-trending discontinuities with minor displacements. Further south, the Mosel trough is cut in longitudinal tectonic blocks, oriented southwest-northeast and asymmetrically tilted towards the river. On the northern valleyside a broad block ex- tending from Trier to Koblenz gently slopes to the southeast. Its faulted northwestern edge is locally accompanied by a secondary flexure. Coming nearer to the Rhine valley, that block is cut across by NNW-SSE-oriented fractures defining orthogonal blocks inclined towards the Rhine axis. Such local NNW-SSE-trending blocks are also observed on the opposite side of the Rhine valley. South of the Mosel, narrow SW-NE-oriented blocks strongly tilt in a step-like manner down to the river, with tilt values up to $6 \mathrm{~mm} / \mathrm{km}$ in a 20-year timespan. They are separated by sharp motion discontinuities occurring on faults whose vertical slip is up to $34 \mathrm{~mm}$ in 20 years. Similar SW-NE-trending blocks, tilted to the northwest, characterize also the western half of the Hunsrück mountains. The individual block tiltings in the Hunsrück are, however, compensated for by fault vertical countermovements, so that this massif as a whole experiences an almost pure vertical motion. The levelling-derived data show moreover, that its eastern part behaves homogeneously and is devoid of significant discontinuities. The Rhine cutting through the southern part of the Rhenish shield up to Koblenz is also tectonically quiet, except for a minor transverse fault at Boppard.

In the southern foreland of the Rhenish shield, the lack of data within a large levelling polygon does not permit investigation of the current tectonic behaviour of the central part of the Permian Saar-Nahe trough. To the west, this region is cut by $\mathrm{N}-\mathrm{S}$-trending fractures separating blocks differently raised, with only locally a tilt component in the vicinity of the Hunsrück border, toward a lowered area. In its castern part, two outward-sloping segments connecting in a simple inflexion point suggest the motion of a SW-NE-trending anticline, whose flanks are furthermore limited by fractures with vertical displaccments up to $21 \mathrm{~mm}$ in 20 years. These fractures extend possibly into the northern part of the Rhine graben, which is otherwise rather quiet and stable, except for an anomalous zone along the Rhine river clearly due to groundwater pumping (Fahlbusch et al., 1983). South of the study area, the Triassic region of the Palatinate mountains appears also as a homogeneous zone, with uplift relative to the adjacent areas. However, this en-bloc movement is disturbed on its western limit by a succession of approximately ENEWSW-oriented faults and a flexure determining a 
step-like lowering toward the northwest of strongly tilted blocks (up to $2.5 \mathrm{~mm} / \mathrm{km}$ in 20 years).

The central segment of the Rhine graben, whose western border is clearly marked by a double discontinuity, either flexured or faulted, is intensely fractured by NW-SE- to NNW-SSE-trending disconti- nuities. The vertical displacements along the border fault amount to $10-11 \mathrm{~mm}$ in 20 years: in the north, the graben is still subsiding but in the south, its western margin is in uplift with regard to its shoulder. The inner fractures delimit small blocks, more or less tilted, acting as minor horsts and grabens.

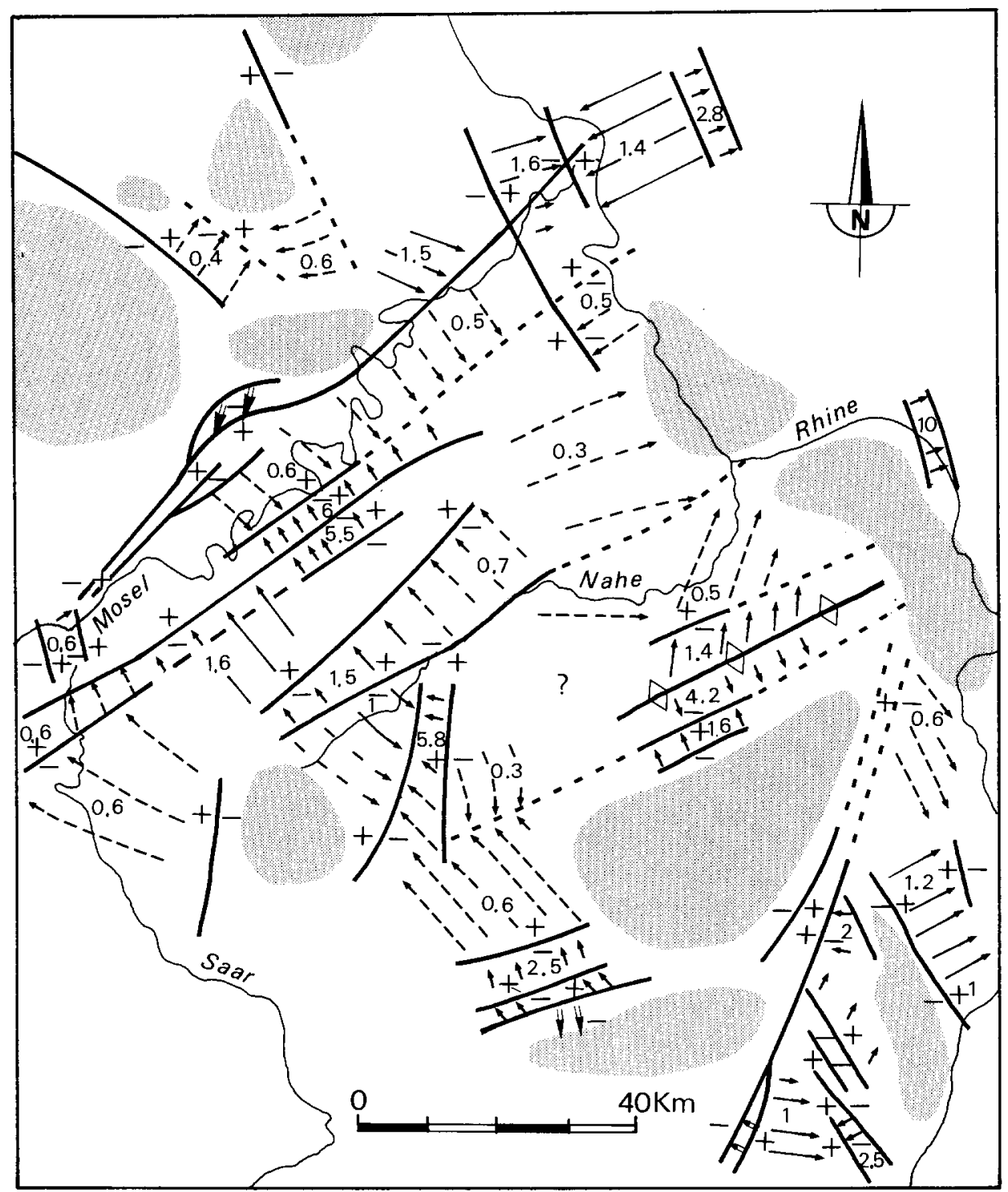

Fig. 5. Map of tectonic blocks and current motions inferred from the levelling comparison. Heavy solid and dashed lines correspond to proved and supposed faults $(+/-$ mentioned in places of observed discontinuities give the movement direction). Arrows point to the lowered side of tilted blocks (tilt values in $\mathrm{mm} / \mathrm{km}$ for a 20 -year period). The areas undergoing pure vertical motion without faulting are figured in light gray. 
North of Landau, one of these motion discontinuities displays the typical profile for a coseismic movement on a high-angle planar normal fault (Stein and Barrientos, 1985), with a superficial displacement on the fault plane approximately fifteen times greater than the relative block movement. Provided only a single sudden motion accounted there for the total height change between both levellings, then that vertical movement would have amounted to 0.3-0.4 $\mathrm{m}$ on the fault plane at the surface. Moreover, two adjacent minor motion anomalies can be interpreted as the traces of conjugate faults.

\section{Geological interpretation of structures and mo- tions}

Most motion discontinuities are sharp changes of segment slope associated with significant vertical displacements. They are interpreted as active faults. However, these motions, though significant, do not generally exceed $34 \mathrm{~mm}$ in about 20 years, and correspond to creep. It is furthermore evident that these geodetically inferred movement rates $(0.5-1.7$ $\mathrm{mm} / \mathrm{yr})$ are not consistent with rates on geologic timespans. This is a well-known fact (Mälzer et al., 1979; Sychev et al., 1986; Demoulin et al., 1992) which could be linked to periodicity of the crustal movements and which excludes any extrapolation of the current rates on longer periods. Moreover, the fault movements are mostly coupled with tilting of the blocks they delimit, in contrast with the purely vertical movements of unfaulted areas. Many motion discontinuities are superposed on either structural or related features, as for instance the NW-SE-oriented alignment of the Quaternary West Eifel volcanoes. Among the major identified structures, the levelling comparison points out the current activity of the Wittlich graben and other tectonic elements along the Mosel valley, the western border fault of the Rhine graben, the Hunsrück border fault and another prominent Variscan fault in the Pirmasens area. Fold reactivation is also sometimes indicated by geodetic data, as for example, a SW-NE-trending anticline axis south of Kreuznach. But motion discontinuities also demonstrate the frequent existence of geologically unknown structures, either extending the influence area of the main fault systems or revealing neotectonic features which are in no way linked to the pre-existing structural framework.

\subsection{The Mosel valley}

In this area, the main active structures extend parallel to the valley, in the SW-NE Variscan direction. The faults bordering the Permian Wittlich graben, north of the Mosel, are presently moving at a rate up to $1 \mathrm{~mm} / \mathrm{yr}$, resulting in a graben uplift with respect to its shoulder. The axis of relative subsidence (or better, of slowest uplift) is about $13 \mathrm{~km}$ further south, on the southern valleyside of the Mosel. The tectonic inversion of the graben, inconsistent with its presumed subsidence of 5-15 and even $35-50 \mathrm{~m}$ in the west since the middle Pleistocene (Negendank, 1977, 1983), is, however, corroborated by similar motions occurring on reactivated Paleozoic faults south of the Mosel river. These high-angle faults, steeply dipping to the northwest in the antivergent zone of the Variscan Mosel syncline (Hoeppener, 1960; Gasser, 1978; Wcijermars, 1986), now act as reverse faults, giving rise to a step-like arrangement of NW-tilted blocks. Moreover, they are seismically active, as indicated by some minor earthquakes recorded along their trace in the 1927-1935 period (Ahorner and Murawski, 1975). The inferred compressive regime could be easily understood in the general stress field of northwestern Europe, with $\sigma_{\mathrm{H}}=\sigma_{1}$ oriented from southeast to northwest. But the in situ stress measurements performed in the Rhenish shield reveal an extensional stress regime for that area (Baumann and Illies, 1983), so we must consider the possibility of either a temporary or a local change in the stress regime along the Mosel valley, with $\sigma_{1}$ turning horizontal. The local character of such a modification is more probable, inasmuch as the general pattern of a crumpled structure south of the Mosel, with block tilting compensated by fault motions, indicates also a predominantly horizontal push exerted on the massif. Moreover, the focal mechanisms of some recent earthquakes in the nearby mountains (Baier and Wernig, 1983) corroborate the compressive type of the stress field at least in parts of the massif. Thus, the extensional regime claimed by Baumann and Illies (1983) for the Rhenish shield as a whole should certainly be restricted to the Eifel area, where an anomalous body of low- 
velocity material has been observed at the mantlecrust boundary, best modelled as a mechanical diapir due to density instability in the asthenosphere (Fuchs et al., 1983).

At the southwestern end of the longitudinal tectonic blocks parallel to the Mosel valley, the levelling comparison indicates motion taking place on a number of minor NNE-SSW- to N-S-trending faults belonging to the eastern flank of the Luxemburg Embayment, northwest of Trier. These are seemingly moving as oblique-slip faults, combining sinistral shear and extension for a vertical movement rate of up to $1 \mathrm{~mm} / \mathrm{yr}$. Transverse fault activity is also identified at the other end of the longitudinal Mosel blocks, on the western and southern margins of the Neuwied basin. In that area, the Mosel terraces already suggest the existence of these transverse faults but do not locate them as accurately as proposed here (Negendank, 1983; Bibus, 1983). In particular, a vertical motion of about $40-50 \mathrm{~m}$ during the Quaternary was inferred either in the Cochem area (Bibus, 1983) or along the Elzbachtal line (Negendank, 1983). Considering present-day vertical movements, the motion discontinuity that we map is located $10 \mathrm{~km}$ further east and corresponds exactly to the southern continuation of the NW-SE-oriented Niedermendig fault. The activity of that fault is furthermore proved by the many micro-earthquakes recorded near Ochtendung between 1977 and 1981, whose distribution and focal mechanisms clearly indicate a purely tensional dip-slip dislocation along a $\mathrm{NW}-\mathrm{SE}$-striking and $60^{\circ} \mathrm{NE}$-dipping plane (Ahorner, 1983). However, the height change trend suggested by the relative position of the levelling segments on each side of the fault for the 1934-1973 period corresponds surprisingly to an opposite movement, by far more important than the seismotectonic slip rate computed from seismic moments of the earthquakes $(0.25-0.50 \mathrm{~mm} / \mathrm{yr}$ against $0.004-0.027$ $\mathrm{mm} / \mathrm{yr})$ ! Such short-term oscillations of vertical motion, though frequently observed at a regional scale (Sychev et al., 1986), remain largely unexplained at the single fault scale.

\subsection{The Hunsrück border fault}

The present-day activity of the Hunsrück border fault is clearly revealed by the levelling comparison.
It is characterized by vertical motions of up to 0.5 $\mathrm{mm} / \mathrm{yr}$ and by a number of local anomalies. The fault movement direction is varying, depending on the place where it is considered: this is probably due to the fact that, in this broad fault zone, the geodetic data indicate in some places the main fault activity and in others minor displacements on conjugate faults. However, the global trend is undoubtedly an uplift of the Hunsrück massif with respect to its southern foreland, in agreement with the PlioQuaternary upheaval of that area. In the upper $10 \mathrm{~km}$ of the crust, the Hunsrück border fault has a high-angle fault character, steeply dipping to the northwest, so that its geodetically inferred vertical motion is compressive, corroborating the NW-SE orientation of the maximum horizontal compression established by in situ stress measurements for that part of northwestern Europe (Baumann and Illies, 1983). Nevertheless, a contradiction arises when considering the focal mechanisms calculated for some earthquakes which recently shook this fault zone. At a depth of $10-15 \mathrm{~km}$, they correspond to extensional dip-slip movements, with a minor right-lateral shear component on a $48^{\circ} \mathrm{SE}$-sloping plane (Ahorner and $\mathrm{Mu}$ rawski, 1975). This is easily explained by the geometry of the Hunsrück border fault (Murawski, 1975), a listric fault which is overturned with respect to the $\sigma_{1}$ axis in the upper $10 \mathrm{~km}$ of the crust (Fig. 6): compression in the upper part of the crust necessarily turns to extension at depth. But one has still to investigate what term of this couple is the driving mechanism of the fault motion. Considering that no deep structure or mantle anomaly has been found in that area to cause primary extension and uplift like in the West Eifel (Neugebauer et al., 1983; Fuchs et al., 1983), we propose that the main tectonic stress acting in the southern Rhenish shield area is a nearsurface SE-NW-oriented compression due to the gravitational push of the Alpine arc on its foreland. Moreover, normal faulting at depth (in the middle part of the crust) revealed by focal mechanisms of earthquakes should be considered as a secondary effect of that compression, due to the fault geometry. This is in agreement with the opinion of Zoback et al. (1993), who suggest that "plate driving forces in the continental lithosphere in this part of western Europe are transmitted principally through the upper crust". 


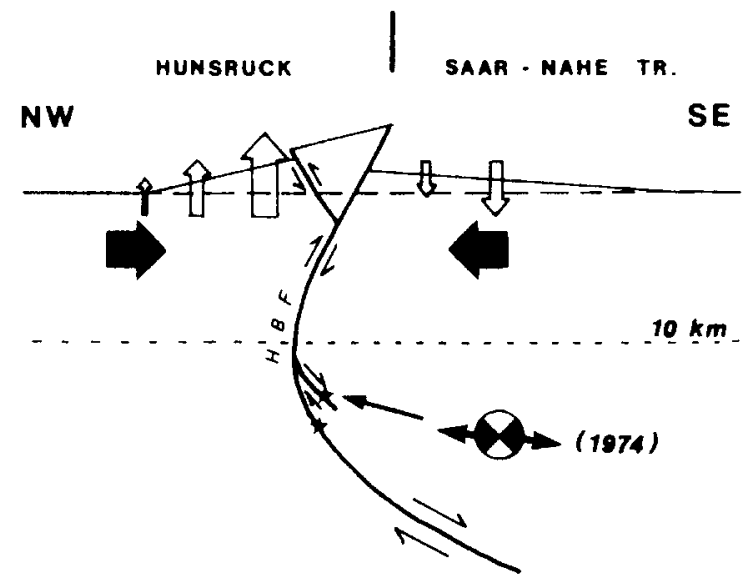

Fig. 6. Diagrammatic sketch showing a cross section of the Hunsrïck border fault $(H B F)$. Due to the fault geometry, nearsurface compression turns to extension at depth. Stars indicate earthquake hypocenters. The Kirn earthquake, 1974, focal mechanism is drawn after Ahorner and Murawski (1975). White arrows describe the vertical crustal motions inferred from geodetic data. The compressive stress in the upper crust is figured by black arrows.

\subsection{The upper Rhine graben}

The activity of the main western border fault of the upper Rhine graben in the Bad Bergzabern-Neustadt a.d. Weinstrasse area is clearly shown by the geodetic data. In that northern half of the $N 35^{\circ} \mathrm{E}$ striking central segment of the graben, opposite fault motions are observed from south to north. In Bad Bergzabern, the western margin of the graben is in uplift with regard to its shoulder (profile $A-A^{\prime}$, Fig. 7); moreover, it is tilted toward the graben axis; the movement which appears flexural in the levelling profile, is probably distributed over two or three major faults. On the contrary, in Neustadt, $30 \mathrm{~km}$ further north, the graben is still in relative subsidence, at a rate of $0.5 \mathrm{~mm} / \mathrm{yr}$, concentrated on a single fracture. Its margin is strongly tilted toward the active western border fault. These opposite vertical motions are understood to be a consequence of moving from the central segment of the graben, deflected towards the $\sigma_{3}$ direction with respect to the regional shear direction $\left(\mathrm{N} 20^{\circ} \mathrm{E}\right)$ and thus submitted to compressional shear, towards the more or less $\mathrm{N}-\mathrm{S}$-trending northern segment, where extensional shear enables further subsidence of the graben (Illies and Baumann, 1982).

In the graben itself, the motion discontinuities mapped in the Landau area are also interesting (profile $\mathrm{A}^{\prime}-\mathrm{A}^{\prime \prime}$, Fig. 7). The major one is interpreted as a NNW-SSE-trending, WSW-dipping normal fault running across the village of Nussdorf, north of Landau. South of it, two minor anomalies correspond probably to antithetic faults. Further north, another NW-striking fault is inferred from two motion discontinuities located west of Speyer. These structures have already been mentioned by Illies and Baumann (1982), who consider them to be extensional faults resulting from a mechanism similar to feather jointing and separating narrow $\mathrm{N} 160^{\circ} \mathrm{E}$-trending horsts and grabens. Oblique to the direction of left-lateral shearing, these pinnate fractures are furthermore confirmed by similarly oriented small scarps, generally $10-15 \mathrm{~m}$ high and by minor offsets of local Rhine tributaries. It is also worth noting that these NNWSSE-trending extensional faults within the graben concentrate on its western margin between Wissembourg and Neustadt a.d. Weinstrasse, where they are probably initiated by the main western border fault geometry: in that area, the azimuth of the border fault changes from $\mathrm{N} 45^{\circ} \mathrm{E}$ in the south to $\mathrm{N} 25^{\circ} \mathrm{E}$ in the north, inducing a change in the stress regime, with the transition from compressional shear to simple shear and then rapidly to extensional shear northwards.

Moreover, the signal displayed by the vertical movement profile in the vicinity of Landau (profile $\mathrm{A}^{\prime}-\mathrm{A}^{\prime \prime}$, Fig. 7) is problematical. Occurring on the small Nussdorf fault, that signal corresponds to a motion of about $40 \mathrm{~cm}$. Such a movement could be ascribed to a levelling error; but even if we accept that the sharp positive spike on the profile may be not valid, a roughly similar signal remains, with fault motion amounting to $20 \mathrm{~cm}$. Compaction of the unconsolidated Neogene sediments of the upper Rhine graben, eventually reinforced by oil pumping, seems also unable to explain that very localized phenomenon, whose lowered part has its uplifted counterpart.

The observed movement should thus be of tectonic origin. In fact, while flexural isostatic response to fault motion, as proposed by Kusznir and Ziegler (1992) to determine that type of profile, appears 


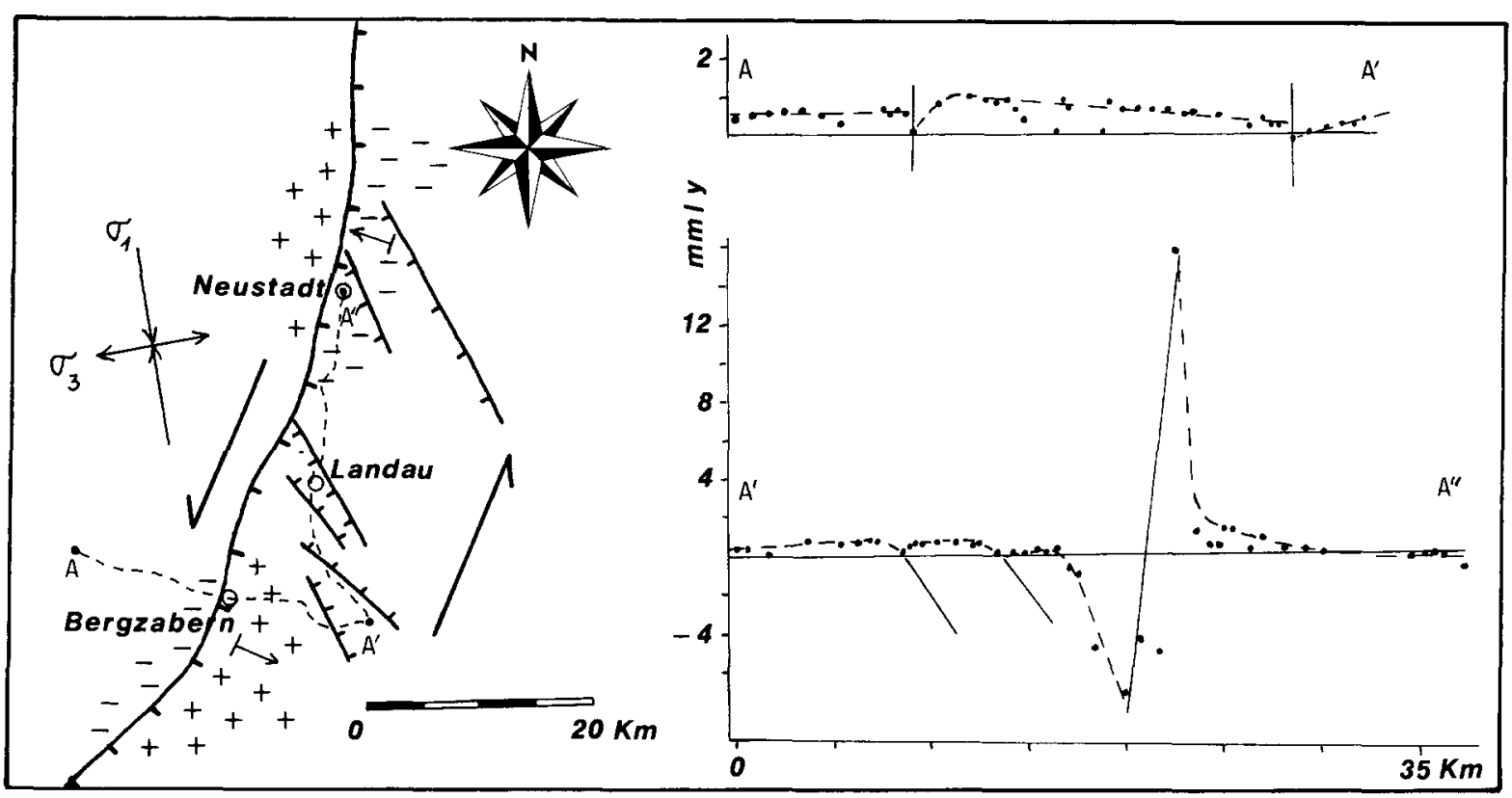

Fig. 7. Relative vertical movements $(+/-)$ at the western Rhine graben border fault in the Landau area, related to the present-day stress field. Arrows indicate the local sense of tilting. The height change variation profiles $A-A^{\prime}$ and $A^{\prime}-A^{\prime \prime}$ clearly show the fault motions discussed in the text.

unlikely at such a small scale, it looks very like the coseismic movement modelled and observed by Stein and Barrientos (1985) for the Borah Peak earthquake, 1983, on a high-angle planar normal fault of the Basin and Range Province (USA). There is a well-marked antithetic flexure (roll-over) of the hanging wall and a corresponding, though less certain rise of the footwall. Relying on this analogy means that the observed movement in Landau is predominantly due to a sudden slip, which has obliterated the long-term fault displacement. Indeed, the Nussdorf fault is a normal fault whose geometry supports an elastic dislocation model fitting the profile $A^{\prime}-A^{\prime \prime}$ (Fig. 7). However, no important earthquake was registered in the Landau area during the inter-levelling period, to produce a motion that is at least two orders of magnitude higher than ground motion expected from tremors commonly occurring in that part of the Rhine graben. We suggest therefore as a hypothesis that an unrecorded swarm of shallow microearthquakes on the Nussdorf fault may be responsible for the vertical movement defined by the levelling comparison near Landau. Since no post-seismic compensation of the coseismic elastic rebound is apparent, this earthquake swarm probably occurred in the late sixties, just before the second survey was performed.

In contrary to the form of the motion, its size remains, however, inconsistent with that hypothesis. The underground presence of oil must probably be taken into account: due to the lubricating effect of oil on the fault plane, the fault may be much weaker than theoretically expected; the ruptures may also propagate in the near-surface realm more easily. Anyway, such a discrepancy in amount between observed and calculated motion has already been noted elsewhere (Castle et al., 1977), but without receiving any satisfying explanation.

\subsection{The Saar-Nahe trough}

In the northwestern part of the Saar-Nahe trough, where few faults, and especially no important fault favourably oriented for a reactivation in the present- 
day stress field are recognized in the Paleozoic basement, the motion discontinuities are by no means less numerous than in the rest of the study area. Since the N-S-trending fractures inferred from the geodetic data could not be related here to known structures, they have been compared to photolineament maps drawn from Landsat2 image analysis (Wahba and Zöller, 1983). On a test area covering the Hunsrück and the western Saar-Nahe trough, such a comparison shows a close relationship between motion anomalies and photolineaments (Fig. 8). However, neither relate to mapped faults. $81.5 \%$ of the significant motion discontinuities coincide with the crossing of a levelling line by a lineament identified on Landsat2, and conversely $43 \%$ of the places where such a lineament cuts a levelling line are characterized by a geodetic anomaly. Taking into account the anomalies whose reliability is more questionable (for instance because it is recorded by a single benchmark), the percentage of photolineations correlating to motion discontinuities even approximates $60 \%$. These currently moving lineaments follow two major directions: the first is the Variscan direction $\left(\mathrm{N} 60^{\circ} \mathrm{E}\right)$, frequently observed in the Hunsrück massif, and the second is a mean N-S direction with fanwise-arranged NW-SE- to NNE$\mathrm{SSW}$-oriented lineations, especially in the northwestern Saar-Nahe trough. Since field checking of photolineaments demonstrates that, if not related to faults, they correspond in most cases to zones of

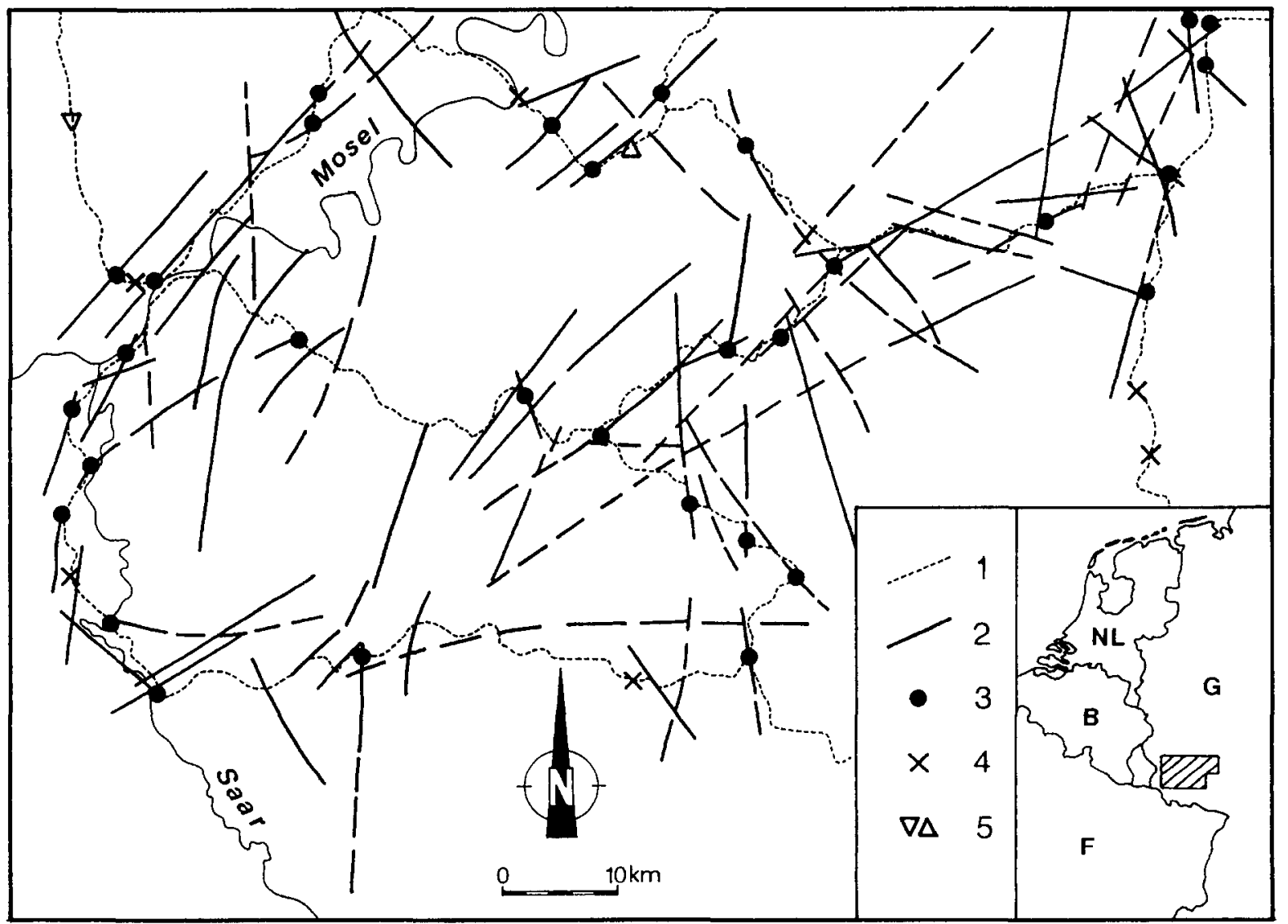

Fig. 8. Close relationship between structural features inferred from the levelling comparison and photolineaments identified on Landsat2 images in the region centred on the Hunsrück. $I=$ first-order levelling line; 2 = photolineament (after Wahba and Zöller, 1983); $3=$ motion discontinuity or anomaly coinciding with a photolineament; $4=$ motion discontinuity; $5=$ local motion anomaly. 
joint concentration (Kronberg, 1977), it is proposed that in areas more or less devoid of major faults favourably oriented for present-day stress relaxation, the tectonic stresses are primarily released by creep on (generally pre-existing) joint systems. In the Saar-Nahe trough, the NW-SE to NNW-SSE-oriented jointing is probably of Hercynian origin, whereas the $\mathrm{N}$-S-oriented joint system is related to the still older $\mathrm{N}-\mathrm{S}$-trending Eifel Depression. According to the current stress field in northwestern Europe (Bergerat, 1987), they are normally undergoing more or less extensional shearing, with predominant strike-slip movements: this is in agreement with the fact that many motion discontinuities related to photolineaments in that area are only local anomalies without any other disturbance, and especially without any relative vertical displacement between the two parts of the segment they interrupt.

\section{Conclusion}

The analytical comparison of geodetic data along levelling profiles is useful as an aid to regional-scale neotectonic studies in intraplate regions. It provides a detailed picture of relative vertical motions and points out movement of individual structural elements, thereby accurately locating the active fractures. In the case of the southwestern Rhenish shield, a complicated active fault pattern is revealed, dividing the massif into a number of tectonic blocks. These display every type of movement (relative subsidence or uplift, tilting). Most faults that are undergoing movement are reactivated, principally along the Variscan trend with compressive motion (Mosel valley, Hunsrück border fault), but movement also occurs in the transverse NW-SE direction or NNE-SSW shear direction of the upper Rhine graben. Some recent, "neotectonic" features could be the extensional faults within the Rhine graben in the Landau area (Villemin and Bergerat, 1987), and possibly the NS-trending fractures of the Saar-Nahe trough, which we explain as former joints now experiencing some displacement. Though the movement rates inferred from the levelling comparison correspond generally to aseismic slip, the faults on which they are observed can also sometimes rupture in minor earthquakes (Landau, Ochtendung, Mosel area).

\section{Acknowledgements}

This paper has greatly benefitted from the constructive critical comments from W.B. Bull, R.H. Groshong, T. Engelder, J.C. Ruegg (reviewers) and J.P. Brun (editor). We wish also to thank H. French, who has corrected the numerous language errors of the first draft of this manuscript.

\section{References}

AdV, 1975. Arbeitsgem. d. Vermessungsverw. d. Länder der BRD: Nivellementnetz 1960. Bayer. Landesvermessungsamt, München.

Ahorner, L., 1983. Historical seismicity and present-day microearthquake activity of the Rhenish massif, central Europe. In: K. Fuchs, K. von Gehlen, H. Mälzer, H. Murawski and A. Semmel (Editors), Plateau Uplift. The Rhenish Shield. A Case History. Springer, Berlin, pp. 198-221.

Ahorner, L. and Murawski, H., 1975. Erdbebentätigkeit und geologischer Werdegang der Hunsrïck-Südrand-Störung. Z. Dtsch. Geol. Ges., 126: 63-82.

Baier, B. and Wernig, J., 1983. Microearthquake activity near the southern border of the Rhenish massif. In: K. Fuchs, K. von Gehlen, H. Mälzer, H. Murawski and A. Semmel (Editors), Plateau Uplift. The Rhenish Shield. A Case History. Springer, Berlin, pp. 222-227.

Baumann, H. and Illies, J.H., 1983. Stress field and strain release in the Rhenish massif. In: K. Fuchs, K. von Gehlen, H. Mälzer, H. Murawski and A. Semmel (Editors), Plateau Uplift. The Rhenish Shield. A Case History. Springer, Berlin, pp. 177-186.

Bergerat, F., 1987. Stress fields in the European platform at the time of Africa-Eurasia collision. Tectonics, 6(2): 99-132.

Bibus, E., 1983. Distribution and dimension of young tectonics in the Neuwied basin and the Lower Middle Rhine. In: K. Fuchs, K. von Gehlen, H. Mälzer, H. Murawski and A. Semmel (Editors), Plateau Uplift. The Rhenish Shield. A Case History. Springer, Berlin, pp. 54-61.

Blundell, D., Freeman, R. and Mueller, S., 1992. A Continent Revealed. The European Geotraverse. Cambridge Univ. Press, Cambridge, $288 \mathrm{pp}$.

Bomford, G., 1971. Geodesy. Oxford Univ. Press, New York, NY, 731 pp.

Castle, R.O., Church, J.P., Elliott, M.R. and Savage, J.C., 1977. Preseismic and coseismic elevation changes in the epicentral region of the Point Mugu earthquake of February 21, 1973. Bull. Seismol. Soc. Am., 67(1): 219-231.

Colleau, A. and Lenôtre, N., 1991. A new digital method for analysis of neotectonics applied to the Bonnevaux-Chambaran area, France. Tectonophysics, 194: 295-305.

Demoulin, A., 1989. Les transgressions oligocènes sur le massif Ardenne-Eifel. Ann. Soc. Géol. Belg., 112: 215-224.

Demoulin, A., Lenôtre, N., Moxhet, J. and Pissart, A., 1992. Les 
régions néotectoniques de la Belgique définies par la comparaison de nivellements. Ann. Soc. Géol. Belg., 115: 99-111.

Ellenberg, J., 1992. Recent fault tectonics and their relation to the seismicity of East Germany. Tectonophysics, 202: 117-121.

Fahlbusch, K., Hein, G. and Kistermann, R., 1983. Rezente Bewegungen im nördlichen Oberrheingraben. Verknüpfung von Messdaten aus Geodäsie, Geologie und Bodenmechanik Neues Jahrb. Geol. Paläontol. Monatsh., pp. 460-476.

Fourniguet, J., 1987. Géodynamique actuelle dans le nord et le nord-est de la France. Mém. BRGM 127, 160 pp.

Fuchs, K., Von Gehlen, K., Mälzer, H., Murawski, H. and Semmel, A., 1983. Epilogue: mode and mechanism of Rhenish plateau uplift. In: K. Fuchs, K. von Gehlen, H. Mälzer, H. Murawski and A. Semmel (Editors), Plateau Uplift. The Rhenish Shield. A Case History. Springer, Berlin, pp. 405-411.

Gasser. U., 1978. Zur tektonischen Problematik der Moselmulde (Rheinisches Schiefergebirge). Geotektonische Forsch., 54: $1-84$.

Hein, G., 1978. Multivariat Analyse der Nivellementsdaten im Oberrheingraben und Rheinischen Schild. Z. Vermessungswes., 103: 430-435.

Hoeppener, R., 1960. Ein Beispiel für die zeitliche Abfolge tektonischer Bewegungen aus dem Rheinischen Schiefergebirge. Geol. Mijnbouw, 39: 181-188.

Holdahl, S.R., 1975. Models and strategies for computing vertical crustal movements in the United States. Int. Symp. Recent Crustal Movements, Grenoble.

Illies, J.H. and Baumann, H., 1982. Crustal dynamics and morphodynamics of the western European rift system. Z. Geomorphol. Suppl., 42: 135-16.5.

Jones, L., 1950. Les premiers résultats de la comparaison du Deuxième Nivellement Général (1948) avec les nivellements anciens. Bull. Soc. Belge Géol. Paleontol. Hydrol., 59: 156 162.

Kronberg, H., 1977. Die regionale und überregionale Bruchtektonik Mitteleuropas. Bestandsaufnahme und Interpretationen. Geotektonische Forsch., 53: 7-41.

Kusznir, N.J. and Ziegler, P.A., 1992. The mechanics of continental extension and sedimentary basin formation: a simpleshear/pure-shear flexural cantilever model. Tectonophysics, 215: $117-131$.

Miilzer, H., Schmitt, G. and Zippelt, K., 1979. Recent vertical movements and their determination in the Rhenish massif. Tectonophysics, 52: 167-176.

Mälzer, H., Hein, G. and Zippelt, K., 1983. Height changes in the Rhenish massif: determination and analysis. In: K. Fuchs, K. von Gehlen, H. Mälzer, H. Murawski and A. Semmel (Editors), Plateau Uplift. The Rhenish Shield. A Case History. Springer, Berlin, pp. 164-176.

Murawski, H., 1975. Die Grenzzone Hunsrück/Saar-Nahe-Senke als geologisch-geophysikalisches Problem. Z. Dtsch. Geol. Ges., 126: 49-62.

Negendank, J.F.W., 1977. Argumente zur känozoischen Geschichte von Eifel und Hunsrück. Neues Jahrb. Geol. Paläontol. Monatsh., pp. 532-548.
Negendank, J.F.W., 1983. Cenozoic deposits of the EifelHunsrück area along the Mosel river and their tectonic implications. In: K. Fuchs, K. von Gehlen, H. Mälzer, H. Murawski and A. Semmel (Editors), Plateau Uplift. The Rhenish Shield. A Case History. Springer, Berlin, pp. 78-88.

Neugebauer, H.J., Woidt, W.D. and Wallner, H., 1983. Uplift, volcanism and tectonics: evidence for mantle diapirs at the Rhenish massif. In: K. Fuchs, K. von Gehlen, H. Mälzer, $H$. Murawski and A. Semmel (Editors), Plateau Uplift. The Rhenish Shield. A Case History. Springer, Berlin, pp. 381-403.

Pissart, A. and Lambot, P., 1989. Les mouvements actuels du sol en Belgique; comparaison de deux nivellements IGN (19461948 et 1976-1980). Ann. Soc. Géol. Belg., 112: 495-504.

Sonne, V. and Weiler, H., 1984. Die detritischen alttertiären (oligozänen) Faunen- und Florenelemente in den Sedimenten des Meerfelder Maares. In: G. Irion and J.F.W. Negendank (Editors), Das Meerfelder Maar. Untersuchungen zur Entwicklungsgeschichte eines Eifelmaares. Courr. Forschungsinst. Senckenberg, 65: 87-95.

Stein, R.S. and Barrientos, S.E., 1985. Planar high-angle faulting in the Basin and Range: geodetic analysis of the 1983 Borah Peak, Idaho, earthquake, J. Geophys. Res., 90(B 13): 11,35511,366 .

Sychev, P.M., Zacharov, V.K. and Semakin, V.P., 1986. On the origin of recent and modern vertical movements in the island systems of northeastern Asia. Tectonophysics, 122: 283-305.

Villemin, T. and Bergerat, F., 1987. L'évolution structurale du fossé rhénan au cours du Cénozoïque: un bilan de la déformation et des effects thermiques de l'extension. Bull. Soc. Géol. Fr., 8, III, 2: 245-25.

Vyskocil, P., Tealeb, A. and Mohamed, A.S., 1991. Recent crustal movement studies at Seiyal area, northwest of Aswan Lake, Egypt. J. Geodyn., 14: 263-276.

Wahba, Y. and Zöller, L., 1983. Terrassenverstellungen und tektonische Analyse von Satellitenbildern. Ein methodischer Versuch, dargestellt an Beispielen aus dem Mosel-Saar-NaheRaum. Eiszeitalter Ggw., 33: 31-30.

Weijermars, R., 1986. $S_{1}$-cleavage fans in the Moselmulde of the Rheinische Schiefergebirge (Federal Republic of Germany) may be due to a $D_{3}$-tectonic event: open folding and reverse faulting. Geol. Rundsch., 75(2): 323-332.

Zippelt, K., 1988. Modellbildung, Berechnungstrategie und Beurteilung von Vertikalbewegungen unter Verwendung von Präzisionsnivellements. Dtsch. Geod. Komm. 343, 153 pp.

Zoback, M.D., Apel, R., Baumgärtner, J., Brudy, M., Emmermann, R., Engeser, B., Fuchs, K., Kessels, W., Rischmüller, H., Rummel, F. and Vernik, L., 1993. Upper-crustal strength inferred from stress measurements to $6 \mathrm{~km}$ depth in the KTB borehole, Nature, 365: 633-635.

Zöller, L., 1983. Neotectonic movements at the southern and western boundary of the Hunstrück mountains (southwestern part of the Rhenish massif). In: K. Fuchs, K. von Gehlen, H. Mälzer, H. Murawski and A. Semmel (Editors), Plateau Uplift. The Rhenish Shield. A Case History. Springer, Berlin, pp. 89-92. 